\title{
Hvordan utdanne en idrettskardiolog?
}

\author{
Idrettskardiologi er en relativt ny fagdisiplin. Den bør være en integrert del av samfunnets fors øk på \\ å forebygge hjerte- og karsykdommer, bekjempe fedmepandemien og skape en sunnere befolkning.
}

Publisert først på nett 8.8. 2012

Idrettskardiologiens mål er å belyse kardiovaskulære effekter av trening innen mosjonsog toppidrett og å avgrense fordeler og risikoer. Dermed kan trygg veiledning gis til dem som engasjerer seg i sportslig aktivitet for å oppnå maksimale helsefordeler med lavest mulig risiko. Den økende etterspørselen etter kompetanse innen idrettskardiologi er kanskje mest synlig i forbindelse med hjertestansene innen toppidretten. Bare i løpet av de siste månedene har det vært flere tilfeller - fotballspillerne Carl-Erik Torp, Fabrice Muamba og Piermario Morosin og svømmeren Alexander Dale Oen. Men den reflekterer også at flere med hjertesykdom og flere eldre bør trene og at flere derfor kan trenge medisinsk assistanse i forbindelse med trening. Dette synliggjør behovet for en systematisk strukturert idrettskardiologisk kunnskapsbase.

I en artikkel som nylig er publisert i European Journal of Preventive Cardiology, går Sports Cardiology Section i the European Society of Cardiology igjennom finnes på Internett. På et interaktivt nettsted presenteres også oppdatert pedagogisk materiale, og nettstedet brukes som plattform for utveksling av ideer og kunnskap innen idrettskardiologien (2).

I den nye artikkelen presenteres en omfattende læreplan for utdanning i idrettskardiologi. Vi påpeker hva som trengs av kunnskap, ferdigheter og holdninger hos leger som skal arbeide med dette. Differensiering mellom fenotyper som reflekterer atletisk aktivitet, såkalt idrettshjerte, og de som betegner hjertesykdom, kan være vanskelig og blir nyansert i artikkelen. Effekt av alder, kjønn, etnisitet, genetiske forhold og sportslig disiplin på hjerteadaptasjonen til idrett belyses. Hjertescreening av idrettsutøvere, som er et forsøk på tidlig identifisering av utøvere som risikerer idrettsrelaterte hjertehendelser og plutselig hjertedød diskuteres. I artikkelen debatteres også etiske og juridisk sider ved screening.

I læreplanen trekker vi frem kardiologiske metoder som må beherskes. Hvilke syk-

\section{«Den økende etterspørselen etter kompetanse innen idrettskardiologi er kanskje mest synlig i forbindelse med hjertestansene innen toppidretten»}

hva en slik kunnskapsbase i form av et kjernepensum i utdanning av idrettskardiologer bør være (1).

\section{Kjernepensum i idrettskardiologi}

Sports Cardiology Section har publisert en rekke anbefalinger om deltakelse i idrett for mennesker med hjertesykdom og om andre aspekter av idrettskardiologien og har kommet med forslag til en felles europeisk screeningprotokoll. Mange av artiklene dommer medfører treningsrelatert risiko? Hvordan diagnostisere dem? Vi diskuterer etiologiske årsaker til hjertestans i idrett og hvilke idretter som er anbefalt for mennesker med hjertefeil. Hjerterehabilitering er nødvendig kunnskap. Rus- og dopingkunnskap er dessverre noe en idrettskardiolog må ha. Sikkerhetsrutiner i idrettsanlegg drøftes.

Denne læreplanen kan fungere som et rammeverk for universiteter og nasjonale og internasjonale helsemyndigheter som vil utvikle opplæringsprogrammer, evalueringer og akkreditering i idrettskardiologi. Europeisk koordinering av læreplanen er fornuftig for å hindre dobbeltarbeid og sikre en mer enhetlig helsetjeneste på tvers av grenser for fagfolk, pasienter og idrettsutøvere.

\section{Idrettsmedisin i Norge}

Hvilke konsekvenser får dette for norsk kardiologiutdanning og for utdanning innen norsk idrettsmedisin? Nordisk idrettsmedisin har tradisjonelt vært orientert mot ortopedi og fysikalsk medisin, søreuropeisk idrettsmedisin har vært mer kardiologirettet. En idrettskardiologisk utdanningsmal er i hvert fall nå tilgjengelig, og det blir lettere å bygge opp idrettskardiologisk kompetanse ut fra den.

\section{Erik Ekker Solberg \\ erik.solberg@diakonsyk.no}

Erik Ekker Solberg (f. 1952) er spesialist i indremedisin og i kardiologi og er autorisert idrettsmedisiner. Han er ansatt ved Diakonhjemmet Sykehus i Oslo. Ekker Solberg er med i ledelsen av Sports Cardiology Section i the European Society of Cardiology.

Forfatter har fylt ut ICMJE-skjemaet og oppgir følgende interessekonflikt: Han har fått reisestipend fra Fond III.

\footnotetext{
Litteratur

1. Heidbuchel H, Papadakis M, Panhuyzen-Goedkoop $\mathrm{N}$ et al. Position paper: proposal for a core curriculum for a European Sports Cardiology qualification. Eur J Prev Cardiol 2012; 19: e-publisert 24.5.

2. Sports Cardiology Section. The European Society of Cardiology www.sportscardiology.eu (29.6.2012)
}

Mottatt 1.7. 2012 og godkjent 5.7. 2012. Medisinsk redaktør Erlend Hem. 